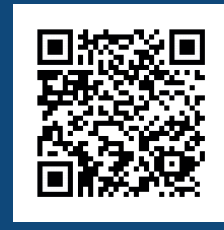

Keywords:

Natural regeneration Coppicing

Silvicultural treatments

Houben Zhao ${ }^{1,2+}$, Zhongmin Wu',2, Zhijun Qiu',2, Zhaojia Li',2, Guangyi Zhou',2

\title{
EFFECTS OF STUMP CHARACTERISTICS AND SOIL FERTILITY ON STUMP RESPROUTING OF Schima superba
}

ZHAO, H.; WU, Z.; QIU, Z.; LI, Z; ZHOU, G.Effects of stump characteristics and soil fertility on stump resprouting of Schima superba. CERNE, v. 24, n. 3, p. 249-258, 2018.

\section{HIGHLIGHTS}

The resprouting probability of $S$. superba was rather high and independent of stump diameter and soil fertility condition but positively affected by stump height.

A fertile soil condition stimulated stumps to generate more resprouts but had no influence on the subsequent resprouts survival and growth.

Stump diameter has no influence on the number of resprouts per stump generated, but facilitated the survival and growth of resprouts.

Stump height is beneficial to the number of resprouts generated but detrimental to resprouts subsequent growth.

\section{ABSTRACT}

Historic:

Received 30/05/2018 Accepted 26/06/2018

Correspondence: cheersritf@I63.com
Schima superba is a widely distributed and broadly planted broadleaf tree in southern China. Information regarding the probability of stump resprouting, characteristics of the growth of resprouts and their influencing factors after disturbance is lacking. In this study, plant survey plots were established in fertile and barren soil conditions one month after a severe ice-snow storm disaster and the resprouting investigations were conducted four years after the treatment. The species showed a rather high $(87.8 \%$ in total) resprouting probability and independent of stump diameter and soil fertility condition but positively affected by stump height. Stumps in fertile soil can generate more resprouts than in barren soil and there is no influence in the subsequent resprouts survival and growth. Stump diameter has no influence on the number of resprouts per stump generated, but facilitated the survival and growth of resprouts. Stump height had a positive influence on resprouts number per stump generated and a negative influence on resprouts growth, but had no significant influence on resprouts survival rate and dominant resprouts growth. We recommend conducting a harvest of $S$. superba at $<30 \mathrm{~cm}$ aboveground level (traditional method). Fertilization immediately following logging or disturbance and artificial resprouts thinning is not recommended for this species.
' Research Institute of Tropical Forestry, Chinese Academy of Forestry, Guangzhou, China

2 Beijiangyuan National Forest Ecosystem Research Station, Nanling Mts. China, Guangzhou, China 


\section{INTRODUCTION}

A natural or human-maded disturbance, such as fire, storms or logging, can damage or kill the aboveground biomass of plants and then partly shape the global biome. However, in many cases of disturbance, the damaged plants in the disturbance often do not die, instead, persist through resprouting (Lawes; Clarke, 20I I). Due to the fully developed root systems and carbohydrate reserves of the parent plant, resprouts can grow faster compared with plants originating from seedlings, which provides resprouts with a competitive advantage in the initial successional stages following disturbances (Petrice; Haack, 20II; Keyser; Zarnoch, 20I4). Thus, the ability to resprout allows a species to persist in a site after a disturbance and has major impacts on species turnover, community structure and the maintenance of biological diversity (Wang et al., 2007).

Stump resprouting can be influenced by various factors, including tree species, disturbance severity (Vesk; Westoby, 2004a; Atwood et al. 2009), tree age (Simões; Marques, 2007), stump size (Randall et al., 2005; Wu et al., 2008), stump height (Kruger; Midgley, 200I), cutting season (Kruger; Midgley, 200I), site quality (Atwood et al., 2009) and habitat conditions such as light (Longbrake; Mccarthy, 200I), soil humidity and fertility (Kabeya et al., 2003). Soil depth also can affecting resprouting capacity and deep soil is favourable to regeneration after disturbance for some species(Lópezsoria; Castell, 1992). Some of these multiple factors have a specific effect on stump sprouting, but most of the effects vary greatly among individuals. Therefore, it is difficult to establish a general model to describe the influence of various factors on stump resprouting. When an unexpected natural disaster such as a storm or fire suddenly occurs, it is difficult to formulate forest management policies after the disaster without an adequate empirical report on the resprouting character of the damaged species. Therefore, research on the resprouting of common and wide-spread species in southern China is critical.

Schima superba is a representative, widely distributed species of broadleaf tree and dominant in the subtropical forests of southern China. This species is valued commercially for its timber and can prevent the spread of fire (Zhang et al., 20I3). Since the 1960s, this species has become an important reforestation tree species in southern China and has been widely planted. Currently, research on the resprouting of $S$. superba after logging or a disturbance is limited or even absent.

In the current study, we investigate the resprouts of S.superba trees damaged in ice-snow storm in two different soil condition sites four years following the disaster. The purpose of this study was to examine the influence of stump diameter, stump height and soil fertility on resprouting ability and subsequent resprouts growth of S. superba.

\section{MATERIAL AND METHODS}

\section{Study sites}

The study site was located at the Tianjinshan Forest Farm $\left(26^{\circ} 24^{\prime} 02^{\prime \prime} \mathrm{N}, 112^{\circ} 58^{\prime} 37^{\prime \prime} \mathrm{E}\right)$ in the northern Guangdong Province, China, which belongs to the central area of the Nanling Mountains and is a transitional region from the south-subtropics to mid-subtropics. The region as a whole has a humid subtropical climate ( $\mathrm{Cfa}$ in Köppen climate classification system) with a mean annual temperature of $19^{\circ} \mathrm{C}$ to $20^{\circ} \mathrm{C}$. The average monthly temperature ranges from $9^{\circ} \mathrm{C}$ in January to $29^{\circ} \mathrm{C}$ in July; the annual precipitation ranges from I,570 to $3,000 \mathrm{~mm}$, most of which mainly occurs between March and August.

The experimental forest that was planted in the 1990s is a mixed plantation in which the dominant tree species are $S$. superba and Mytilaria laosensis in the foothills and S. superba at the ridge of a hill. The two places were divided into fertile and barren soil respectively according soil fertility based on Total N, P, K and SOM. The terrain facing the northeast is gently sloped at $15^{\circ}$, and the soil is yellow soil derived from granite and can classified as Luvic Alisols according WRB 2006. The experimental forest in Tianjinshan also irrevocably suffered severe damage in the ice-storm in 2008, and many M. laosensis and $S$. superba trees were broken at the trunk.

\section{Experimental design and sprout measurements}

One month after of the ice-storm disaster, we outlined 3 plant sample plots both in fertile and barren soil places. The size of each sample plot was $30 \mathrm{~m} \times 30 \mathrm{~m}$, and the distance between plots was farther than $50 \mathrm{~m}$. One soil profile was dug to bedrock in each plot to survey the soil depth. Soil samples at depths of 0-10, 10-20, 20-30, and $30-50 \mathrm{~cm}$ from every plot were collected with soil auger. There were 5 sampling points in every plot, and soil collected from the same layer were mixed and treated as one sample, and macroscopic stones, litter, roots, and other organic debris were removed. The soil was sieved with a 2-mm-bore-diameter sieve, air dried and stored in darkness before use. The soil $\mathrm{pH}$ of a I:2.5 soil: I mol. $\mathrm{L}^{-1}$ $\mathrm{KCl}$ suspension was measured with a $\mathrm{pH}$ meter. Soil organic matter (SOM) in the soil was determined using the Walkley-Black dichromate oxidation method. Total $\mathrm{N}$ was determined using the Kjeldahl method. Total P was 
extracted with $\mathrm{H}_{2} \mathrm{SO}_{4}$ and $\mathrm{HClO}_{4}$ and measured with a spectrophotometer. Total $\mathrm{K}$ was determined with a flame photometer after the samples were digested with $\mathrm{HNO}_{3}$ and $\mathrm{HClO}_{4}$. Total exchangeable base was extracted with $\mathrm{NH}_{4} \mathrm{OAc}$, dissolved with $\mathrm{HCl}$ solution and titrated against $\mathrm{NaOH}$. The cation exchange capacity (CEC) was analyzed by inductively coupled plasma atomic emission (ICP) (VISTA-MPX). The results of the property analyses of soils from the fertile and barren sites are presented in Table I.

The S. superba trees with broken trunks from the sample plots were selected to conduct a resprouting survey. In the study, 53 and 62 trees were selected from the fertile and barren soil sites, respectively, and marked and treated in March 2008 to carry out the sprouting experiment. To ensure that all the stump buds remained safe and were not mechanically damaged, a treatment was determined such that the sample tree trunks were sawed below the naturally broken position using a handsaw at a noncracked position of the main bole. Finally, II 5 stump samples were obtained. The stump basal diameter and stump height of each stump were recorded.

Resprout measurements were conducted in the fourth year following the stump sawing treatment. The surveys were done in June 2012, and a vernier caliper and surveying rod were used. A stump with at least one living resprout was considered successful resprouting. The recorded measurement indexes included the survival condition (alive or dead) of every resprout, basal diameter of each dead and living resprout, and height of every resprout. The longest resprout was considered to be the dominant resprout.

Statistical analyses

Chi-square tests were used to analyze the difference in quantity between the living and dead stump in fertile and barren soil. One-way Anova LSD tests were used to analyze the difference among stumps and resprouts in different soil condition site.
A binary logistic regression was utilized to analyze the effects of soil fertility, stump diameter and stump height on the stump survival via resprouting 4 years after a disaster. Because the number of dead stumps did not exceed five times the number of independent predictor variables for a hierarchical regression, we analyzed each independent factor individually. The logistic model has the following form I, where $P(S)$ is the probability of resprouting, $\beta_{0}$ and $\beta$, are the model coefficients, and $x_{1}$ is the soil condition (rich or poor), stump diameter or stump height.

$P(S)=\frac{1}{\left(1+\exp \left[-\left({ }^{2}{ }_{0}+{ }^{2}{ }_{1} x_{1}\right)\right]\right)}$

The influence of soil fertility, stump diameter and stump height on resprouting ability, resprout numbers, resprout survival probability, resprout basal diameter, resprout length and dominant resprout length was analyzed using a multiple linear regression analysis. The regression model has the following form 2, where is predicted value of the sprouting ability indicators, including number, survival rate, basal diameter and length of resprouts, $\beta_{0}$ is the model constant, $\beta_{1}, \beta_{2}$ and $\beta_{3}$ are partial regression coefficients, $x_{1}, x_{2}$ and $x_{3}$ are soil condition, stump diameter and stump height, respectively. To eliminate the effects of the unit and dimension of the independent variables on dependent variables, standardized coefficients were introduced to compare the influence of different factors on the resprouting ability.

$$
(\hat{y})=\beta_{0}+\beta_{1} x_{1}+\beta_{2} x_{2}+\beta_{3} x_{3}
$$

The correlations between resprout numbers, resprout basal diameters, resprout length and dominant resprout length were analyzed using Pearson correlation coefficients.

All statistical analyses were performed using SPSS I7.0 for Windows, and an alpha of 0.05 was used to determine significant differences.

TABLE I Site habitats and top soil $(0-30 \mathrm{~cm})$ properties.

\begin{tabular}{|c|c|c|c|c|c|c|c|c|c|}
\hline Site & $\begin{array}{l}\text { Depth } \\
(\mathrm{cm})\end{array}$ & $\begin{array}{l}\text { Layer } \\
(\mathrm{cm})\end{array}$ & $\mathrm{pH}$ & $\begin{array}{l}\text { SOM } \\
\left(\mathrm{g} \cdot \mathrm{kg}^{-1}\right)\end{array}$ & $\begin{array}{c}\mathrm{TN} \\
\left(\mathrm{g} \cdot \mathrm{kg}^{-1}\right)\end{array}$ & $\begin{array}{c}\text { TP } \\
\left(g \cdot \mathrm{kg}^{-1}\right)\end{array}$ & $\begin{array}{c}\text { TK } \\
\left(\mathrm{g} \cdot \mathrm{kg}^{-1}\right)\end{array}$ & 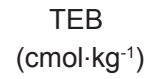 & 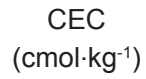 \\
\hline \multirow{4}{*}{ Soil fertile } & \multirow{4}{*}{$\begin{array}{r}92.0 \\
\pm 1.7 \mathrm{a}\end{array}$} & $0-10$ & $4.31 \pm 0.12 a$ & $46.34 \pm 9.2 a$ & $1.78 \pm 0.55 \mathrm{a}$ & $0.23 \pm 0.04 a$ & $14.11 \pm 3.5 \mathrm{a}$ & $0.83 \pm 0.1 \mathrm{la}$ & $5.05 \pm 0.59 a$ \\
\hline & & $10-20$ & $4.43 \pm 0.1 \mathrm{la}$ & $31.88 \pm 2.7 a$ & $1.17 \pm 0.07 a$ & $0.17 \pm 0.04 a$ & $12.56 \pm 2.6 \mathrm{a}$ & $0.43 \pm 0.08 a$ & $3.92 \pm 0.2 \mathrm{la}$ \\
\hline & & $20-30$ & $4.43 \pm 0.07 a$ & $29.34 \pm 4.3 a$ & $0.97 \pm 0.06 a$ & $0.14 \pm 0.01 \mathrm{la}$ & $11.80 \pm 3.1 \mathrm{a}$ & $0.62 \pm 0.38 \mathrm{a}$ & $3.90 \pm 0.27 a$ \\
\hline & & $30-50$ & $4.49 \pm 0.10 \mathrm{a}$ & $23.83 \pm 5.6 \mathrm{a}$ & $0.80 \pm 0.06 a$ & $0.14 \pm 0.02 a$ & $11.74 \pm 2.9 \mathrm{a}$ & $0.46 \pm 0.30 \mathrm{a}$ & $3.75 \pm 0.20 \mathrm{a}$ \\
\hline \multirow{4}{*}{ Soil barren } & \multirow{4}{*}{$\begin{array}{l}111.0 \\
\pm 3.5 b\end{array}$} & $0-10$ & $4.47 \pm 0.03 a$ & $2 \mathrm{I} .40 \pm 4.3 \mathrm{~b}$ & $0.74 \pm 0.18 b$ & $0.15 \pm 0.00 a$ & $4.46 \pm 0.45 b$ & $0.31 \pm 0.04 a$ & $3.15 \pm 0.27 b$ \\
\hline & & $10-20$ & $4.53 \pm 0.02 a$ & $14.06 \pm 7.5 b$ & $0.47 \pm 0.15 b$ & $0.12 \pm 0.02 a$ & $4.35 \pm 0.54 b$ & $0.18 \pm 0.01 \mathrm{a}$ & $2.89 \pm 0.49 a$ \\
\hline & & $20-30$ & $4.57 \pm 0.06 a$ & $9.02 \pm 4.12 b$ & $0.40 \pm 0.03 a$ & $0.14 \pm 0.00 \mathrm{a}$ & $4.34 \pm 0.67 b$ & $0.15 \pm 0.02 a$ & $2.72 \pm 0.52 \mathrm{a}$ \\
\hline & & $30-50$ & $4.77 \pm 0.09 b$ & $5.20 \pm 1.98 b$ & $0.26 \pm 0.02 \mathrm{a}$ & $0.13 \pm 0.00 \mathrm{a}$ & $4.37 \pm 0.68 b$ & $0.25 \pm 0.0 \mathrm{la}$ & $2.54 \pm 0.6 \mathrm{la}$ \\
\hline
\end{tabular}

Notes: $\mathrm{pH}$ (soil: $\mathrm{KCl}$ solution= I:2.5); SOM (Soil organic matter); TN (Total nitrite); TP (Total phosphorus); TK (Total potassium); TEB (Total exchangeable base); CEC (Cation exchange capacity). The data following the \pm symbol is standard error. Means with different letters are significantly different at a significance level of $\mathrm{P}<0.05$. 


\section{RESULTS}

\section{Probability of resprouting}

The species shows agreat probability of resprouting. The proportion of resprouting reached to $84.9 \%$ and $90.3 \%$ in fertile soil and barren soil respectively, and the difference between which is not significant (Table 2). Also, the stump diameter ranged from $6.5 \mathrm{~cm}$ to $23 \mathrm{~cm}$ in fertile soil, which is much larger than in barren soil, whose stump diameter ranged from $3.0 \mathrm{~cm}$ to $21.5 \mathrm{~cm}$. A living or dead stump in fertile and barren soil doesn't vary with the diameter, which indicates that the stump diameter has nothing to do with the probability of resprouting. There was no significant difference between the two sites, with the stump height ranged from $16 \mathrm{~cm}$ to $180 \mathrm{~cm}$ in fertile soil and $10 \mathrm{~cm}$ to $280 \mathrm{~cm}$ in barren soil. Simultaneously, the length of living stumps is much larger than dead stumps in both fertile soil and barren soil, which indicates that the height of the stump plays an important role in promoting the probability of resprouting.

Based on the statistical result given above, the data of the stump height from the fertile soil and barren soil were combined to analyze the relationship between the stump height and probability of resprouting, and the regression model is depicted in Figurel, in which the lowest probability of resprouting is $54.7 \%$ when the stump height is as low as $10 \mathrm{~cm}$ and it rises with the stump height, reaching $68.3 \%$ when the stump height is $30 \mathrm{~cm}$, and the stump height is commonly reserved when logged.

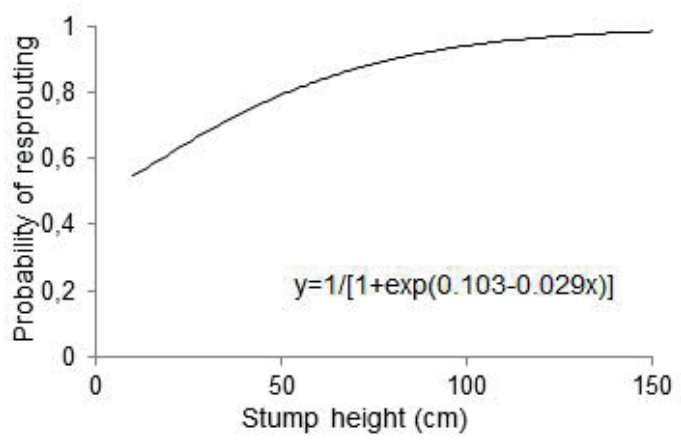

FIGURE I Relationship between the stump height and probability of sprouting four years after an ice-snow disaster using binary logistic regression model coefficients.
Resprouting abundance, survival rate and growth rate

The soil fertility is closely linked with the total number of resprouts of each stump. Stumps of S. superba in a fertile soil have nothing to the survival rate and growth of resprouts but sprout more resprouts than in barren soil (Table 3). Stump diameter had no significant influence on the number of resprouts, but has positive influence on resprouting survival and growth rate (Figure 2). Moreover, stump height is favourable to the increase of resprouting abundance, but it goes against to resprouts growth, and yet it doesn't make any difference to the survival rate and growth rate of resprouts (Figure 3).

TABLE 3 Differences of the resprouts total number, survival rate, growth rate and dominant resprouts growth in different soil condition.

\begin{tabular}{cccccc}
\hline $\begin{array}{c}\text { Soil } \\
\text { condition }\end{array}$ & $\begin{array}{c}\text { Resprout } \\
\text { total } \\
\text { number }\end{array}$ & $\begin{array}{c}\text { Resprout } \\
\text { survival rate } \\
(\%)\end{array}$ & $\begin{array}{c}\text { Resprout } \\
\text { basal } \\
\text { diameter } \\
(\mathrm{cm})\end{array}$ & $\begin{array}{c}\text { Resprout } \\
\text { length } \\
(\mathrm{m})\end{array}$ & $\begin{array}{c}\text { Dominant } \\
\text { resprout } \\
\text { length } \\
(\mathrm{m})\end{array}$ \\
\hline \multirow{2}{*}{ Fertile } & 33.22 & 34.18 & 1.82 & 1.99 & 3.63 \\
& $\pm 2.20 \mathrm{a}$ & $\pm 1.77 \mathrm{a}$ & $\pm 0.1 \mathrm{la}$ & $\pm 0.13 \mathrm{a}$ & $\pm 0.17 \mathrm{a}$ \\
\cline { 2 - 6 } Barren & 25.25 & 32.85 & 1.78 & 1.76 & 3.43 \\
& $\pm 1.46 \mathrm{~b}$ & $\pm 1.33 \mathrm{a}$ & $\pm 0.12 \mathrm{a}$ & $\pm 0.12 \mathrm{a}$ & $\pm 0.17 \mathrm{a}$ \\
\hline
\end{tabular}

The data following the \pm symbol is standard error. Means with different letters are significantly different at a significance level of $P<0.05$..

The number of resprouts that each stump generated was inextricably bond to the soil environment and the height of stump, and of which the latter is more influential than the former. Four years after the treatment, we found that the resprouts survival rate is significantly related to the stump diameter, but has nothing to do with the soil environment and the height of stump. Reflected by resprout basal diameter and length, the growth rate of resprouts was positively and negatively influenced by the stump diameter and the height of stump respectively. The growth rate of the dominant resprout was more significant for the restoration of trees, relative to the average growth rate of all the resprouts. In this study, dominant resprout growth rate was positively influenced by stump diameter but has no correlation with soil fertility condition and stump height (Table 4).

TABLE 2 Differences in the stump number, diameter and height between living and dead stumps in different soil condition.

\begin{tabular}{|c|c|c|c|c|c|c|}
\hline \multirow{2}{*}{ Soil condition } & \multicolumn{2}{|c|}{ Stump number } & \multicolumn{2}{|c|}{ Stump diameter $(\mathrm{cm})$} & \multicolumn{2}{|c|}{ Stump height $(\mathrm{cm})$} \\
\hline & Alive & Dead & Alive & Dead & Alive & Dead \\
\hline Fertile & 45 & 8 & $10.71 \pm 0.52 a$ & $8.44 \pm 0.56 a b$ & $113.31 \pm 7.10 a$ & $61.63 \pm 19.10 b$ \\
\hline Barren & 56 & 6 & $8.69 \pm 0.48 b$ & $7.20 \pm 0.46 b$ & $105.09 \pm 7.85 a$ & $21.83 \pm 4.10 b$ \\
\hline
\end{tabular}

The data following the \pm symbol is standard error. Means with different letters are significantly different at a significance level of $\mathrm{P}<0.05$. 

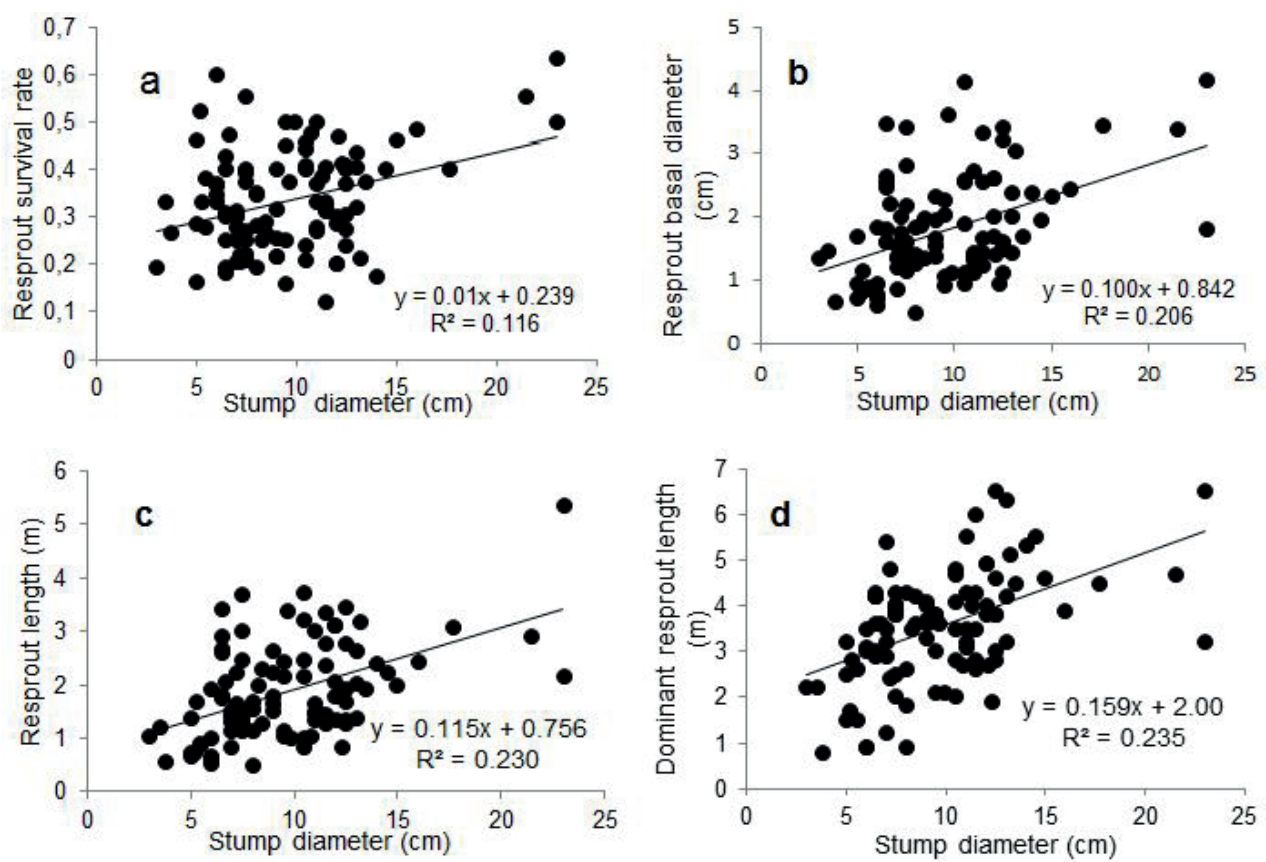

FIGURE 2 Relationship between stump diameter and resprout survival rate (a), resprout basal diameter (b), resprout length (c) and dominant resprout length (d) of S. superba.
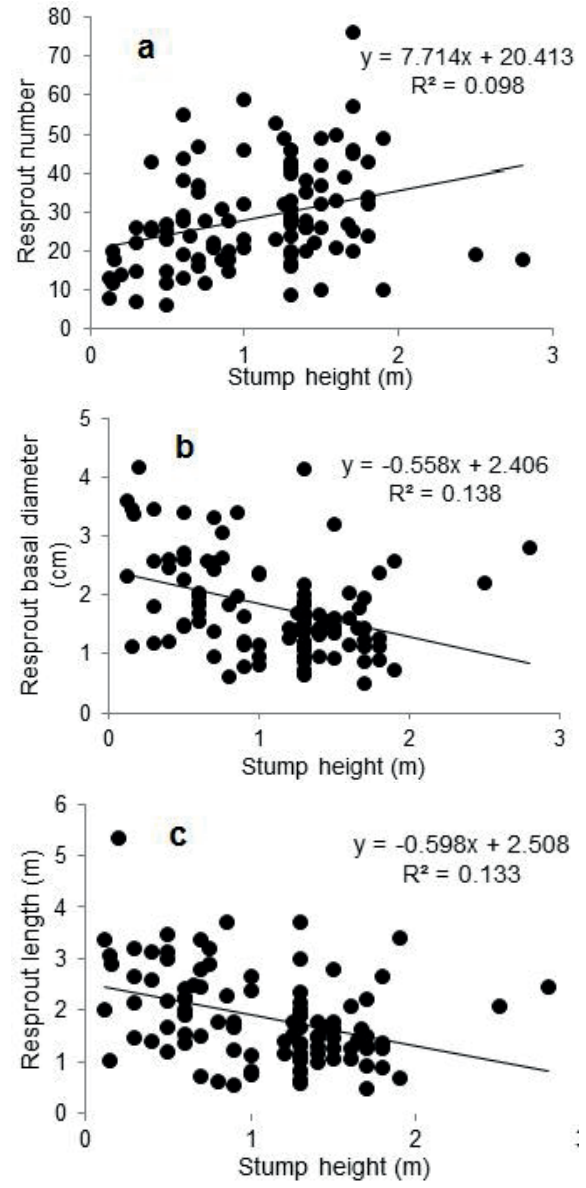

FIGURE 3 Relationship between stump height and resprout number (a), resprout basal diameter (b) and resprout length (c) of S. superba.

\section{Correlations between sprouting indicators}

The two resprout growth indicators, basal diameter and length, are closely correlated (Table 5). The resprout number was negatively associated with the resprout basal diameter and length, which means that if a stump produces a large number of resprouts, the resprouts will be small and short. The dominant resprout length was positively correlated with the entire resprout basal diameter and length but was not influenced by the total number of resprouts, which means that, no matter how many more or less resprouts a stump produces, the growth of the dominant sprout is unaffected.

\section{DISCUSSION}

\section{Resprouting ability of S. superba}

Resprouting is a common phenomenon when woody plants are disturbed by anthropogenic damage such as cutting or logging (Imanishi et al., 2010) and natural disasters such as hurricanes or fire (VESK, 2006). For example, Beck and Hooper (1986) found that $86 \%$ of all dominant/co-dominant tree stems were composed of stump sprouts 20 years after clearcutting a southern Appalachian mixed hardwood stand. Similarly, Keyser and Zarnoch (2014) investigated the stump survival of nine hardwood species, and the resprouting rate was up to $60 \%-98 \%$ three years after clearcutting. In this study, the stump of $S$. superba has a high probability of sprouting 
TABLE 4 Summary of the multiple linear regression analysis of the effects of stump size and soil fertility on resprout number, survival and growth and the elongation of dominant resprouts.

\begin{tabular}{|c|c|c|c|c|c|c|c|c|c|c|}
\hline \multirow[t]{2}{*}{ Factors } & \multicolumn{2}{|c|}{ Resprout } & \multicolumn{2}{|c|}{ Resprout } & \multicolumn{2}{|c|}{$\begin{array}{c}\text { Resprout } \\
\text { basal diameter }\end{array}$} & \multicolumn{2}{|c|}{$\begin{array}{l}\text { Resprout } \\
\text { length }\end{array}$} & \multicolumn{2}{|c|}{$\begin{array}{c}\text { Dominant resprout } \\
\text { length }\end{array}$} \\
\hline & number & P-value & survival rate & P-value & SC & P-value & SC & P-value & $\mathrm{SC}$ & P-value \\
\hline Soil fertility & 0.260 & 0.009 & -0.041 & 0.687 & -0.065 & 0.473 & 0.040 & 0.659 & -0.044 & 0.636 \\
\hline Stump diameter & 0.059 & 0.556 & 0.361 & 0.001 & 0.408 & $<0.001$ & 0.405 & $<0.001$ & 0.480 & $<0.001$ \\
\hline Stump height & 0.307 & 0.002 & 0.044 & 0.660 & -0.270 & 0.003 & -0.272 & 0.003 & -0.069 & 0.454 \\
\hline
\end{tabular}

Notes: Statistically significant results are in bold, SC represents standardized coefficients..

TABLE 5 Correlation coefficients between resprout numbers, resprout basal diameters, resprout length and dominant resprout length. The symbol * represents a significant correlation.

\begin{tabular}{cccc}
\hline $\begin{array}{c}\text { Correlation } \\
\text { coefficient }\end{array}$ & $\begin{array}{c}\text { Resprout basal } \\
\text { diameter }\end{array}$ & $\begin{array}{c}\text { Resprout } \\
\text { length }\end{array}$ & $\begin{array}{c}\text { Dominant resprout } \\
\text { length }\end{array}$ \\
\hline $\begin{array}{c}\text { Resprout number } \\
\text { Resprout basal } \\
\text { diameter }\end{array}$ & $-0.452^{*}$ & $-0.383^{*}$ & -0.080 \\
Resprout length & - & $0.945^{*}$ & $0.648^{*}$ \\
\hline
\end{tabular}

(84.9\% in a fertile site and $90.3 \%$ in a poor site), which indicates that this species can persist in a site for a long time after a disturbance, and this ability can be used as an important source of regeneration in forest production.

Various factors have been reported to influence the ability of stumps to sprout, and among these factors, the physiology of plants is the internal and conclusive mechanism. Vesk (2006) demonstrated that ground plants maintained considerable resprouting ability throughout the plant's lifetime to recover from damage caused by terrestrial herbivores or fire; trees are able to avoid many disturbances by being tall and decrease their resprouting ability with age. Resprouting woody plants rely on non-structural carbohydrate (NSC) storage to fuel respiration and regrowth until the plant has recovered the photosynthetic capacity to support these costs (Schutz et al., 20II; Zhu et al., 20I2). Resprouters typically reserve more NSC than obligate seeders through both accumulation, when availability exceeds the requirements for growth, and by reserve formation, when storage is at the expense of growth to ensure a rapid resprouting response to a disturbance (Nzunda et al., 20 I4). Myers and Kitajima (2007) showed that shadetolerant species tend to have more NSC reserves in shady evergreen rainforest habitats than light-demanding species. For S. superba in this study, the shade- and poornutrient-tolerant traits indicate that this species may be trading off height growth for resource storage, which enables $S$. superba to obtain a high resprouting ability after a disturbance. Also, the ice-snow storm occurred during the winter season, and this fact may be another reason that $S$. superba obtained a high resprouting ability because the carbohydrate reserve in the root system is abundant in the dormant season (Kays; Canham, 199I). Previous research on other species has also demonstrated that cutting or damage in the dormant season benefits residual stump regeneration by resprouting (Hamberg et al., 20I I; Xue et al., 20I2).

Influence of stump diameter on resprouting

Within a species, the probability of resprouting is significantly related to the parent tree age and/or stump diameter. The relationship of stump diameter and resprouting ability has been well documented, and this relationship seems to vary with species. Generally, smaller diameter or younger aged stumps have a better resprouting probability (Randall et al., 2005; Ashish et al., 20I0), and this rule has been demonstrated in a large number of species of different types, such as oak species (Šplichalová et al., 2012; Keyser; Loftis, 2015) , rain forest species (Bellingham; Sparrow, 2009), temperate broadleaved species (Ashish et al., 2010), and broad-leaved subtropical species (Mishra et al., 2003). However, there are also many species that have an increased resprouting ability with the parent tree stump diameter (Vesk, 2006; Matula etal., 2012), or have no relationship with stump size (Keyser; Zarnoch, 20I4). In many cases, the relationship between resprouting probability and tree size and/or age is not linear but unimodal. For example, most deciduous tree species have a high resprouting ability for stumps with a diameter ranging from $5 \mathrm{~cm} \sim 15 \mathrm{~cm}$ (Del Tredici, $200 \mathrm{I}$ ); the number of sprouts peaked in the stumps with diameters of $10.8 \mathrm{~cm} \sim 46.5 \mathrm{~cm}$ in liaodong oaks (Rong et al., $20 \mathrm{I} 3$ ), $20 \mathrm{~cm} \sim 35 \mathrm{~cm}$ in sessile oaks (Šplichalová et al., $20 \mathrm{I} 2), 10 \mathrm{~cm} \sim 20 \mathrm{~cm}$ in white oaks and $20 \mathrm{~cm} \sim 50$ $\mathrm{cm}$ in black oaks (Sands; Abrams, 2009). The mechanism by which plants alter their resprouting ability with age is not very clear and may include a number of causes. Vesk (2006) notes that this phenomenon may be explained by the adaptation of a plant to a disturbance. Trees are exposed to damage from herbivores and other sources; 
resprouting ability is necessary at the seedling stage, and trees can avoid many disturbances by being large and tall, when the resprouting ability may be less necessary. Apart from adaptation, other mechanisms, such as gene, physiology and texture, also have been demonstrated to contribute to stump resprouting (Clarke et al., 2013). Large stumps often have a large surface, more buds, a much more complete root system and store more available carbohydrate, compared with small stumps, and can support more stump resprouts (Clarke et al., 20I3). In contrast, buds may senesce over time, resulting in few vigorous buds for resprouting on large stumps (Vesk; WestobyY, 2004b), and buds also may be trapped within the thick bark of advanced-age stumps.

Our results showed that the stumps of $S$. superba with larger diameter tended to have a higher resprouting probability and resprout number than with small diameter, but there were no statistically significant differences. This result was partly confirmed by the results of Lynch and Bassettt (1987) who reported that the resprouting ability of northern red and northern pin oak stumps was independent of diameter. This result also corroborates the findings of Keyser and Zarnoch (2014) who reported that the probability of resprouting of 7 shade-tolerant midstory species was independent of the tree size. There was no decline in resprouting ability with the stump diameter of $S$. superba observed in this study, possibly because of the biological features of shade- and low-soil-nutrient-tolerance of this species. The stumps of $S$. superba in this research $(5 \mathrm{~cm} \sim 24 \mathrm{~cm}$ in diameter) were not as large as previously reported species; therefore, the senescence of dormant buds may not yet be displayed.

In our study, the stump diameter of S. superba had a positive correlation with the resprout survival rate, which may due to the developed root systems and abundance reserved food, allowing for the support of more sprouts. The large number of living resprouts indicated a powerful resprouting ability in a short term, but for long-term trends, the resprouted clumps will self-thin over time and finally result in a few stems per stump (Retana et al., 1992). In contrast with sprout production, sprouts, especially dominant sprout growth, seem more important as rapid growth occurring after a disturbance causes sprouts to take up a large area and obtain a competitive advantage for subsequent growth. In this study, the stump diameter of $S$. superba had a positive influence on the sprouts and dominant sprout growth during the observation period. This result agrees with the results of Matula (2012), who reported that the bigger and therefore older lime trees produced taller and larger diameter sprouts in larger quantities than younger trees after they were cut down.

\section{Influence of stump height on resprouting}

Like the stump diameter, the stump height also has been shown to influence the resprouting probability and the sprout growth (Hamberg et al., 20II, Xue et al., 2012). High stumps may produce more resprouts and facilitate sprout growth due to the availability of more carbohydrate reserves and more dormant buds on the stumps (Ashish et al., 2010; Xue et al., 2012). For example, Skovsgaard et al. (2006) reported that the number of resprouts and their growth rates increased with increasing stump height. It is important to note that the stimulation of resprouting by stump height seems valid in a short term because the nutriment stored in the aboveground tissue is limited. The advantage of higher stumps on resprouting tends to continue for one (Randall et al., 2005; Xue et al., 2012) or two (Peter et al., 2006) growing seasons after a disturbance and vanishes after carbohydrate reserves are exhausted. Additionally, ongoing respiratory demands of a large amount of aboveground tissue may prevent sprout growth. In many other studies, the stump height also was reported to have no significant influence (Hamberg et al., 20I I; Petrice; Haack, 20II) or even a negative effect on resprouting (Johansson, 2008).

Our results indicated that higher stumps of $S$. superba tend to have a higher resprouting probability and generate more living sprouts after damage. Similar results have been found in other species, such as aspen (Bell et al., 1999), willow (Karlsson; Albretson, 200I) and beech (Peter et al., 2006), by previous studies. The growth of resprouts decreased with the height of the stump in our results, which may due to the trade-off between resprout number and resprout growth (see below). However, the length of the dominant resprout was not influenced by the stump height, which indicates that the stump height may have a small effect on sprout growth as the non-dominant species will die by self-thinning in the following growth.

\section{Influence of soil fertility on resprouting}

Generally, plants growing on low resourcesupplying soil tend to allocate more resources to storage and yield a high resprouting probability after being damaged by disturbances (Cruz; Moreno, 200I). Many field observations studies have reported that the resprouting probability is negatively related to site quality (Forrester et al., 2003; Buhk et al., 2007). Similar to some 
species previously reported, the stumps of S. superba grown on a nutrient-poor site before disturbance had a higher stump survival rate and generated a greater number of sprouts in our results. Resprouts can generate both from stumps and roots and the absence of one structure can compensated by another (Ferreira et al., 2017). Plants grow in deep soil often have a more developed root system than that grow in shallow soil and gain a more advanced resprouting capacity (Lópezsoria; Castell, 1992). In this experiment, the resprouts mainly generate from stump collars, so the depth of the soil does not show the advantage for resprouting. Poor soil water levels and nutrient contents usually directly limit sprout growth because these resources usually control primary productivity (Cruz et al., 2002). However, contrasting opinions also note that the growth of resprouting plants may be less sensitive to these limitations, due to their developed root systems and reduced competition in post-disturbance environments (Midgley, 1996). In our results, the growth of resprouts including the dominant resprouts was not influenced by the soil fertility condition, which indicated that the resprouts growth, at least at the initial stage of resprouting, was not limited by soil nutrient content. The same results also have been reported in plants such as Erica australis, a strong resprouter from the western Mediterranean (Cruz; Moreno, 200I). In this sense, fertilization immediately following disturbance usually does not increase the growth of resprouts.

The relationship between sprout number, basal diameter, length and dominant length

In our observation, the two resprout growth description parameters, resprout basal diameter and length, were positively correlated (correlation coefficient approach to I), which means that the growth of resprout diameter and length is linked, and these two parameters play the same role in describing resprout growth. There was a significantly negative relationship between the number of resprouts per stump and the resprout growth present in our study. The same relationship in many other species has also been reported in previous studies (Xue et al., 2012; Rong et al., 2013). These results are consistent with the Midgley (1996) principle that there is a trade-off between sprouting and height growth. It seems that stumps from a low-nutrient soil field and/or with a high residual stump tend to produce a large number of sprouts, but the sprouts cannot grow well due to the limited resources reserved in the root system and the intensive competition for space and nutrients among the sprouts. However, a large number of resprouts often leads to a high mortality (Lutz; Halpern, 2006) and a rapid selfthinning process in Quercus crispula, Populus tremula, Betula pendula, and Betula pubescens after coppicing (Rydberg, 2000). Therefore, the negative influence of sprout number on sprout growth may be valid in a short term.

Numerous resprouts per stump decreased the resprout growth but had no significant influence on the elongation of dominant resprouts in this study. This result conflicts with Xue et al. (20I2), who reported a significant negative relationship between the dominant sprout length and the number of sprouts per stump after cutting on $Q$. variabilis. Only dominant resprouts can survive and finally grow to canopy height, therefore, artificial thinning sprouts in the early period of a resprouting restoration process is not necessary in forest management after a disturbance, although this method has been proven to benefit the remaining sprout growth (Keyes et al., 2008; Atwood et al., 2009).

\section{CONCLUSIONS}

S. superba exhibited a high probability of stump resprouting, and most of the resprouts could remain alive four years after an extreme ice-snow storm. Hence, resprouting is considered to be a reliable and predictable restoration method after a natural disturbance or in regeneration after the logging of $S$. superba. The stump diameter had a slightly positive influence on the resprouting probability and the number of resprout, and was significantly beneficial to the survival and growth rate of resprouts and dominant resprouts. The higher residual stumps had a more vigorous resprouting ability and generated more resprouts per stump but disadvantaged the resprouts following growth. We recommend conducting a harvest of $S$. superba at $<30 \mathrm{~cm}$ aboveground level (traditional method). A poor soil fertility condition benefits stump survival and stimulates the stump to generate more resprouts after a disturbance but has no influence on resprout growth. Fertilization immediately following a disturbance is not recommended. A large number of resprouts per stump inhibited resprout growth but had little influence on the dominant resprout growth, which implies that artificial sprout thinning is a matter of choice and not a necessity in this species.

\section{REFERENCES}

ASHISH, P.; LATIF, K. M.; KUMAR, D. A. Effect of stump girth and height on resprouting of Rhododendron arboreum following disturbance in temperate mixed broad leaved forest of Arunachal Pradesh, India. Journal of Forestry Research, v. 2I, n. 4,p. 433-438, 2010.

ATWOOD, C. J.; FOX T. R.; LOFTIS D. L. Effects of alternative silviculture on stump sprouting in the southern Appalachians. Forest Ecology and Management, v. 257, n. 4, p. I305-1313, 2009. 
BELLINGHAM, P. J.; SPARROW, A. D. Multi-stemmed trees in montane rain forests: their frequency and demography in relation to elevation, soil nutrients and disturbance. Journal of Ecology, v. 97, n. 3, p. 472-483, 2009.

BUHK, C; MEYN, A.; JENTSCH, A. The challenge of plant regeneration after fire in the Mediterranean Basin: scientific gaps in our knowledge on plant strategies and evolution of traits. Plant Ecology, v. 192, n. I, p. I-19, 2007.

CLARKE, P. J.; LAWES, M. J.; MIDGLEY, J. J.; LAMONT, B. B.; OJEDA, F.;BURROWS, G. E.; ENRIGHT, N. J.; KNOX, K.J. E. Resprouting as a key functional trait: how buds, protection and resources drive persistence after fire? New Phytologist, v. 197, n. I, p. 19-35, 2013.

CRUZ, A.; MORENO, J. M. Lignotuber size of Erica australis and its relationship with soil resources. Journal of Vegetation Science, v. I2, n. 3, p. 373-384, 200 I.

CRUZ, A.; PÉREZ, B.; QUINTANA, J. R.; MORENO, J. $M$. Resprouting in the Mediterranean-type shrub Erica australis afffected by soil resource availability. Journal of Vegetation Science, v. I3, n. 5, p. 64I-650, 2002.

DEL TREDICI, P. Sprouting in temperate trees: a morphological and ecological review. Botanical Review, v. 67, n. 2, p. I2I-I40, $200 \mid$.

FERREIRA, M.C.; RODRIGUES, S.B.; VIEIRA, D.L.M. Regeneration through resprouting after clear-cutting and topsoil stripping in a tropical dry forest in central Brazil. Revista Árvore, v. 4I, n. 2, p. e410218, 2017.

FORRESTER, D.; BAUHUS, J.; CONNELL, M. Competition in thinned Silvertop Ash (Eucalyptus sieberi L. Johnson) stands from early coppice growth. Forest Ecology and Management, v. I74, n. I-3, p. 459-475, 2003.

IMANISHI, A.; MORIMOTO, J.; IMANISHI, J.; SHIBATA, S.; NAKANISHI, A.; OSAWA, N.; SAKAI, S. Sprout initiation and growth for three years after cutting in an abandoned secondary forest in Kyoto, Japan. Landscape and Ecological Engineering, v. 6, n. 2, p. 325-333, 2010.

KABEYA, D.; SAKAI, A.; MATSUI, K.; SAKAI, S. Resprouting ability of Quercus crispula seedlings depends on the vegetation cover of their microhabitats. Journal of Plant Research, v. II6, n. 3, p. 207-216, 2003.

KEYSER, T.; LOFTIS, D. Stump sprouting of 19 upland hardwood species I year following initiation of a shelterwood with reserves silvicultural system in the southern Appalachian Mountains, USA. New Forests, v. 46, n. 3, p. 449-464, 2015.

KEYSER, T. L.; ZARNOCH, S. J. Stump sprout dynamics in response to reductions in stand density for nine upland hardwood species in the southern Appalachian Mountains. Forest Ecology and Management, v. 319 n. 5, p.29-35, 2014.

KRUGER, L. M.; MIDGLEY, J. J. The influence of resprouting forest canopy species on richness in Southern Cape forests, South Africa. Global Ecology and Biogeography, v. I0, n. 5, p. 567-572, 200 I.
LAWES, M.; CLARKE, P. Ecology of plant resprouting: populations to community responses in fire-prone ecosystems. Plant Ecology, v. 212, n. 12, p. 1937-1943, 201 I.

LONGBRAKE, A. C. W.; MCCARTHY, B.C. Biomass allocation and resprouting ability of princess tree (Paulownia tomentosa: Scrophulariaceae) across a light gradient. The American Midland Naturalist, v. I46, n. 2, p. 388-403, 200 I.

LÓPEZSORIA, L. ; CASTELL, C. Comparative genet survival after fire in woody Mediterranean species. Oecologia, v. 91, n. 4, p. 493-499, 1992.

LUTZ, J. A.; HALPERN, C. B. Tree mortality during early forest development: a long-term study of rates, causes, and consequences. Ecological Monographs, v. 76, n. 2, p. 257-275, 2006.

MIDGLEY,J.J. Why the world's vegetation is not totally dominated by resprouting plants? because resprouters are shorter than reseeders. Ecography, v. 19, n. I, p. 92-95, 1996.

MISHRA, B. P.; TRIPATHI, R.S.; TRIPATHI, O. P.; PANDEY, H. N.; MISHRA, B. P.; TRIPATHI, O. P. Effect of disturbance on the regeneration of four dominant and economically important woody species in a broad- leaved subtropical humid forest of Meghalaya, northeast India. Currentence, v. 84, n. II, p. I449-I453, 2003.

MYERS, J.A.; KITAJIMA, K. Carbohydrate storage enhances seedling shade and stress tolerance in a neotropical forest. Journal of Ecology, v. 95, n. 2, p. 383-395, 2007.

NZUNDA, E. F;; GRIFFITHS, M. E.; LAWES, M. J. Resource allocation and storage relative to resprouting ability in wind disturbed coastal forest trees. Evolutionary Ecology, v. 28, n. 4, p. 735-749, 2014.

PETER, S.J.; NORDFJELL, T.; HOLMGÅRD, S. R. I. Precommercial thinning of beech (Fagus sylvatica L.): Early effects of stump height on growth and natural pruning of potential crop trees. Scandinavian Journal of Forest Research, v. 21, n. 5, p. 380-387, 2006.

PETRICE, T. R.; HAACK, R. A. Effects of cutting time, stump height, and herbicide application on Ash (Fraxinus Spp.) stump sprouting and colonization by Emerald Ash Borer (Agrilus planipennis). Northern Journal of Applied Forestry, v. 28, n. 3, p. 223-23I, 201 I.

RANDALL, C. K.; DURYEA, M. L.; VINCE, S.W.; ENGLISH, R.J. Factors influencing stump sprouting by pondcypress (Taxodium distichum var. nutans (Ait.) Sweet). New Forests, v. 29, n. 3, p. 245-260, 2005.

RETANA, J.; RIBA, M.; CASTELL, C.; ESPELTA, J. M. Regeneration by sprouting of holm-oak (Quercus ilex) stands exploited by selection thinning. Vegetatio, v. 99I00, n. I, p. 355-364, 1992. 
RONG, L.; WENHUI, Z.; JINGFENG, H.; JIANYUN, Z. Survival and development of Liaodong oak stump sprouts in the Huanglong Mountains of China six years after three partial harvests. New Forests, v. 44, n. I, p. I-12, 2013.

SANDS, B. A.; ABRAMS, M. D. Effects of stump diameter on sprout number and size for three oak species in a Pennsylvania clearcut. Northern Journal of Applied Forestry, v. 26, n. 3, p. 122-125, 2009.

SCHUTZ, A. E. N.; BOND, W. J.; CRAMER, M. D. Defoliation depletes the carbohydrate reserves of resprouting Acacia saplings in an African savanna. Plant Ecology, v. 212, n. 12, p. 2047-2055, $201 \mathrm{l}$.

SIMÕES, C. G.; MARQUES, M. C. M. The Role of Sprouts in the Restoration of Atlantic Rainforest in Southern Brazil. Restoration Ecology, v. I5, n. I, p. 53-59, 2007.

ŠPLÍCHALOVÁ, M.; ADAMEC, Z.; KADAVÝ, J.; KNEIFL, M. Probability model of sessile oak (Quercus petraea (Matt.) Liebl.) stump sprouting in the Czech Republic. European Journal of Forest Research, v. 131, n. 5, p. 1611-1618, 2012.

VESK, P. A. Plant size and resprouting ability: trading tolerance and avoidance of damage? Journal of Ecology, v. 94, n. 5, p. 1027-1034, 2006.

VESK, P. A.; WESTOBY, M. Sprouting ability across diverse disturbances and vegetation types worldwide. Journal of Ecology, v. 92, n. 2, p. 310-320, 2004a.
VESK, P. A.; WESTOBY, M. Funding the bud bank: a review of the costs of buds. Oikos, v. 106, n. I, p. 200-208, 2004b.

WANG, X.; KENT, M.; FANG, X. Evergreen broad-leaved forest in Eastern China: its ecology and conservation and the importance of resprouting in forest restoration. Forest Ecology and Management, v. 245, n. I, p. 76-87, 2007.

WU, L.; SHINZATO, T.; CHEN, C.; ARAMOTO, M. Sprouting characteristics of a subtropical evergreen broad-leaved forest following clear-cutting in Okinawa, Japan. New Forests, v. 36, n. 3, p. 239-246, 2008.

XUE, Y.; ZHANG, W.; ZHOU, J.; MA, C.; MA, L. Effects of stump diameter, stump height, and cutting season on Quercus variabilis stump sprouting. Scandinavian Journal of Forest Research, v. 28, n. 3, p. 223-23I, 2012.

ZHANG, R.; ZHOU, Z.; LUO, W.; WANG, Y.; FENG, Z. Effects of nitrogen deposition on growth and phosphate efficiency of Schima superba of different provenances grown in phosphorus-barren soil. Plant and Soil, v. 370, n. I-2, p. 435-445, 2013.

ZHU, W.; XIANG, J.; WANG, S.; LI, M. Resprouting ability and mobile carbohydrate reserves in an oak shrubland decline with increasing elevation on the eastern edge of the Qinghai-Tibet Plateau. Forest Ecology and Management, v. 278, n. 6, p. II8-126, 2012. 